\title{
Роль германских военных в истории ранней Веймарской республики
}

\begin{abstract}
Аннотаиия. Рассматривая историю Веймарской Германии, автор выдвигает главный тезис, согласно которому свобода была прочграна не в 1933 г., когда Гитлер пришел к власти, а еше ранъше - в 1920 г. Данное положение раскрывается через призму анализа трансформаиии кайзеровской армии и роли немеиких военнъх на раннем этапе республики. Несмотря на поражение в Первой мировой войне, смену политической власти, ограничения, введеннъе Версальским мирным договором, армия по-прежнему стремилась отстоять свою самостоятельность и остатвся не орудием государства, а его оличетворением. Военное руководство не выстраивало отношений с представителями власти. Подчеркиваются противоречивость политического курса сочиал-демократов, несоответствие мероприятий правительства по реформированию армии ожиданиям рядовых иленов партии, слабость и непоследовательность политического контроля над армией. Командование рейхсвера, формально соблюдая Версальские договоренности и конституиионные рамки, создавало профессиональную армию и разрабатывало планы по продолжению реализачии германской политики мирового господства. С одной стороны, это вызывало протест со стороны пачифистского движения, в котором принимали активное участие как представители демократической общественности, так и офииеры-пачифисть. С другой сторонъ, милитаристский дух способствовал становлению сил парамилитаризма, ставших опорой наиионал-сочиалистов.
\end{abstract}

Ключевые слова: германская революиия, Первал мировая война, Версальский договор, Веймарская республика, рейхсвер, фрайкоры, Капповский пути, паиифизм, парамилитаризм, Густав Носке.

Review. Reviewing the history of Weimar Germany, the author puts forward the thesis that freedom was lost not in 1933 when Hitler came to power, but even earlier - in 1920. This view is presented through the lens of an analysis of the transformations in the Kaiser army and of the role of the German soldiers in the early stages of the new republic. Despite defeat during the First World War, the change in political power, the limitations imposed by the peace treaty of Versailles, the army still sought to defend its independence and to remain not the government's tool, but its personification. Military leadership constructed its relationship directly with government representatives. The author underlines the inconsistency of the social-democrats' political course, the incoherence of the government actions aimed at reforming the army according to the expectations of the party members, the weakness and inconsequence of the political control over the army. The command of the Reichwehr, though formally adhering to the Versailles agreements and constitutional frames, organised a professional army and developed plans for the continued realisation of Germany's policy of world supremacy. On the one hand, this aroused protests from the pacifist movement in which representatives of the democratic community, as well as officerspacifists took an active part. On the other hand, the militaristic spirit contributed to the emergence of paramilitaristic forces that became the pillar of the national-socialists.

Key words: Kapp-Putsch, Freikorps, Reichswehr, Weimar Republic, Treaty of Versailles, First World War, German revolution, pacifism, paramilitarism, Gustav Noske.

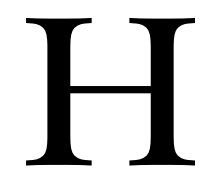

оябрьская революция 1918 г. - германская революция [13] - окрылила надежды многих современников. После окончания более чем четырехлетней войны, которая подвергла людей крайне тяжелым испытаниям как на фронтах, так и на их родине, жизнь наконец-то должна была вернуться в нормальное русло. В течение многих месяцев участники крупных массовых демонстраций выступали с требованиями «Мира, свободы и хлеба». Старый режим, ответственный за развязывание войны, должен был исчезнуть с политической арены вместе с кайзером и военной кастой. Революция открыла путь к демократии. За это прогрессивные силы Германии не прекращали бороться начиная с революции 1848-1849 гг. Теперь, в декабре 1918 г., Всегерманский съезд советов рабочих и солдатских депутатов Германии определил дату выборов в Национальное собрание и наметил пути развития парламентской системы правления.

Первые годы существования Веймарской республики оказались для судеб первой германской демократии решающими. Сегодня боль- 


\section{Проблемы войны и мира}

DOI: $10.7256 / 2222-1972.2015 .3 .16520$

шинство историков сходятся во мнении, что упущения и недостатки на этапе создания республики стали непосредственной причиной ее гибели [19]. В кризисные 1930-1933 гг. республику уже едва ли можно было спасти из-за возникших в ее фундаменте трещин, ход событий стали определять национал-социалисты. Оглядываясь назад, можно сказать, что свобода была проиграна уже в 1920 [11], а не в 1933 г.

После 1918 г. одной из ключевых политических фигур стал социал-демократ Густав Носке [16]. Председатель СДПГ и СНУ Фридрих Әберт возложил на него ответственность за проведение политики в военной сфере, которая с точки зрения власти имела особое значение. После окончания Первой мировой войны районы боевого применения той части армии, которая еще не была демобилизована, переместились с театров военных действий за пределами Германии вглубь страны. Если раньше речь шла о сражениях против внешнего врага, то теперь предстояла борьба против внутреннего врага. Средства при этом остались прежними.

Носке, под началом которого оказались армия и флот, получил в свое распоряжение ту мощную силу, которая представляла собой стержень власти в кайзеровской Германии, а теперь, на этапе демобилизации, оказалась в состоянии развала и одновременного процесса реструктуризации, ориентированного на будущее. Появление социал-демократа на посту военного министра являлось совершенно новым для того времени. До 1914 г. прусская армия находилась в состоянии непримиримой внутриполитической конфронтации с социал-демократией [8]. Несмотря на то что большинство депутатов рейхстага от СДПГ проголосовали за предоставление правительству военных кредитов, в период 1914-1918 гг. отношения между армией и социал-демократией не улучшились. Это и неудивительно, если учитывать ту политическую роль, которую играли военные в то время. В 1916-1918 гг. Верховное командование сухопутных войск (ОХЛ) во главе с генерал-фельдмаршалом Паулем фон Гинденбургом и генералом Әрихом Людендорфом установило в стране военную диктатуру. Верховное командование предписывало кайзеровскому правительству, по какому пути оно должно идти при осуществлении политики. Прусские военные рассматривали себя не как орган, находящийся на службе у государства, и не как на инструмент политики, а как воплощение самой сути государства.
Носке, войдя в правительство СНУ, должен был считаться с такой ментальностью военных. Она продолжала существовать, несмотря на то что поражение в Первой мировой войне и революция значительно ослабили влияние высшего военного руководства. Вопрос о будущем профессиональных военных в Германии оставался открытым. Правда, Эберт принял принципиальное решение, когда в ноябре 1918 г. заключил союз с генералом Вильгельмом Грёнером. Он не верил в то, что армию можно было вернуть на родину без опоры на старые командные структуры, а поэтому старался избежать разрыва с влиятельным генералитетом.

На этапе революционного перехода от кайзеровской империи к республике Носке казался по-настоящему «сильным человеком» в правительстве. Современники говорили даже об «эре Густава Носке». Одновременно это свидетельствовало и о существенных особенностях первых лет Веймарской республики: в центре внимания общества находились вопросы об участии армии во внутриполитических событиях, а также о стремлении военных кругов вернуть себе определяющую роль в государстве.

Бездействие нового министра рейхсвера в момент революции имело более серьезные последствия, чем его действия. Он не смог использовать имевшиеся возможности для осуществления новой военной политики. Закон о народном ополчении, опубликованный правительством 12 декабря 1918 г., требовал создания новой военной организации, преданной республике. Военно-политическая программа Всегерманского съезда советов рабочих и солдатских депутатов, принятая в середине декабря 1918 г., в своей основе также была нацелена на «разгром милитаризма». Тем самым советы стремились лишить монархический офицерский корпус доминирующих позиций во власти. Демократически настроенная общественность - т. е. значительное большинство тех немцев, которые участвовали в революции или, по крайней мере, симпатизировали ей, - ожидала скорейшей реализации намеченной программы военно-политических реформ.

Носке не удалось решить эти задачи, или, точнее, он брался за них, но действовал крайне нерешительно. Возникшие в первые месяцы 1919 г. военные формирования, назвавшие себя «фрайкоры» и образовавшие основу будущего рейхсвера, были чем угодно, но только не надежным инструментом республики. Профессио- 


\section{Исторический журнал: научные исследования № 3 (27) • 2015}

DOI: $10.7256 / 2222-1972.2015 .3 .16520$

нальные военные и солдаты, которые не хотели или не могли вернуться к гражданской жизни, предпочли пойти другими путями.

Деятельность Носке в начале 1919 г., когда еще ничего не было решено, свелась главным образом к насильственному умиротворению страны. За это его хвалили представители правых. Считалось, что ему не оставалось ничего иного, кроме как опереться на монархические и враждебные республике военные круги, поскольку иначе государственный порядок был бы разрушен. Сам Носке рассматривал свои действия именно в такой системе координат: он говорил, что ему пришлось реагировать на леворадикальные, порой насильственные выступления быстро, решительно и с использованием преимущественно военной силы. Это было необходимо сделать для того, чтобы в первую очередь защитить выборы в Национальное собрание, а потом и молодую немецкую республику от опасностей, угрожавших ей с левого фланга. В дальнейшем он претендовал на то, чтобы считать «борьбу против большевизма» своей личной исторической заслугой.

На самом деле большевистской угрозы как фактора, серьезно влиявшего на политическую власть в Германии, в тот период не существовало. Однако вышедшие из массового антивоенного движения революционные или леворадикальные силы с их отрицанием милитаристского государства бросали принципиальный идейный вызов старым элитам. Последние пустили в ход легенду об «ударе кинжалом в спину» воюющей армии. Иными словами, сразу после окончания Первой мировой войны старые элиты взяли на прицел в качестве «козлов отпущения» за поражение те политические силы, которые с 4 августа 1914 г. выступали с антивоенными лозунгами.

Профессиональные военные, в свою очередь, после окончания войны занялись поисками нового врага и нового поля деятельности, чтобы подтвердить свое право на существование - как в настоящем, так и в будущем. Офицеры из штаба расквартированной в Берлине Гвардейской кавалерийской стрелковой дивизии представляли своему министру отчеты о военной ситуации, в которых стихийные массовые демонстрации приобретали характер организованного восстания. Однако народный уполномоченный, ответственный за армию и флот, не счел нужным запросить дополнительную информацию у рабочих и солдатских советов, в большинстве своем ориентированных на социал-демократию, и, таким образом, сформировать собственную картину внутриполитического соотношения сил. Тем самым он потакал устремлениям военных (и не только немецких) продолжить «войну после войны», на сей раз против внутреннего врага. Судя по всему, министру рейхсвера за все время пребывания в этой должности не пришло в голову, что обеспечение порядка внутри страны - задача не армии, а полиции. Следует признать, что силы полиции, в т. ч. и в столице рейха Берлине, в это время были достаточно слабыми и что они, возможно, отказались бы стрелять в собственный народ.

Схожие с гражданской войной столкновения во многих крупных городах Германии в Берлине, Бремене, Мюнхене и других - стоили жизни многим тысячам человек. Фрайкоровцы, получившие приказ открывать стрельбу, не церемонились со своими врагами. Таких человеческих жертв в ходе внутренних конфликтов не было в Германии со времен Тридцатилетней войны XVII в. Так гражданская война стала настоящим отличительным знаком «эры Носке». Лидеры фрайкора стали выдвигать политические требования, пытались сами делать политику, например, саботировать заключение мирного договора, и не раз подумывали о том, не провозгласить ли им диктатуру. Чем самоувереннее выступали военные, тем меньше свободы действий оставалось у министра рейхсвера. Он уже не мог избавиться от тех духов, которых сам же вызвал к жизни, наоборот, он сам, не замечая того, стал их пленником.

Это наглядно проявилось в период между подписанием Версальского мирного договора летом 1919 г. и путчем Каппа-Люттвица в марте 1920 г. Носке оказался не в состоянии предотвратить военный путч против республики. Критики возложили на него ответственность за то, что всего лишь через полтора года после начала революции прусско-германский милитаризм вновь смог поднять голову и подвергнуть молодую, еще совершенно не окрепшую республику тяжелым испытаниям.

Путч наглядно показал, насколько изменилось внутриполитическое соотношение сил за полтора года после 9 ноября 1918 г., когда социал-демократ Филипп Шейдеман провозгласил германскую республику [16]. Теперь Германия была вынуждена наблюдать за тем, как военное формирование, а именно - морская бригада Эрхарда, изгнало из Берлина республиканское пра- 


\section{Проблемы войны и мира}

DOI: $10.7256 / 2222-1972.2015 .3 .16520$

вительство Густава Бауәра (СДПГ). Вместо него генерал барон фон Люттвиц вместе с чиновником Вольфгангом Каппом предпринял попытку образования т. н. национального правительства, не обладавшего демократической легитимацией. За развитием событий внимательно наблюдал популярный генерал Первой мировой войны Әрих Людендорф, чтобы в случае необходимости также предложить свои услуги путчистам.

Рейхсвер, созданный Носке из остатков кайзеровской армии, показал свое истинное лицо. Он не предпринял ничего для защиты законного правительства Густава Бауэра, а заявил о своем нейтралитете. Начальник войскового управления генерал Ганс фон Сект произнес тогда многозначительную фразу: «Рейхсвер не стреляет в рейхсвер!» Другими словами: армия республики, которая до этого без всяких угрызений совести стреляла в революционно настроенных рабочих, не пожелала выступить против войск путчистов. Ведь они являлись выходцами из того же общественного слоя, к которому они причисляли себя как носители корпоративного армейского духа.

Не военные отразили Капповский путч против республики, а всеобщая забастовка, объявленная правительством вместе с СДПГ, НСДПГ, профсоюзами и Коммунистической партией (КПГ). Завершившиеся успехом совместные действия для отражения первой попытки правых радикалов насильственно захватить власть в Германии, однако, не привели к укреплению республики. На следующих выборах в рейхстаг «Веймарская коалиция» - СДПГ, Центр и Германская демократическая партия (ГДП) - утратила большинство, принадлежавшее ей до этого момента, в пользу союза правых сил.

После путча по непонятным причинам генерал фон Сект не только не был снят со своей должности, а наоборот, был назначен командующим сухопутными войсками в качестве преемника лояльного вюртембергского генерала Вальтера Рейнхардта. Рейхспрезидент Эберт не воспрепятствовал этому ошибочному решению. Сект занялся «нейтрализацией» 5000 путчистов из бригады Эрхарда и морской бригады Лёвенфельда. Под этим он, однако, понимал не уголовное преследование изменников родины, а повторное зачисление состава этих формирований на военную службу и их использование против борющейся под руководством коммунистов «Красной армии Рура», возникшей в результате всеобщей забастовки.
Значительная часть путчистов была принята на службу в рейхсвер Веймарской республики. Другие скрылись за границей, как, например, капитан Вальдемар Пабст, отдавший в январе 1919 г. приказы убить Карла Либкнехта и Розу Люксембург, а потом участвовавший в подготовке путча. Третьи присоединились к организации «Консул», одной из самых опасных праворадикальных террористических групп веймарского периода, отличившейся подготовкой и реализацией громких политических убийств.

Военный путч выявил как глубокую пропасть между рейхсвером и республикой, так и бессилие правительства перед лицом рейхсвера. Тот факт, что период после отставки Носке был назван не по имени его преемника на посту министра рейхсвера, политика Отто Гесслера (ГДП), а по имени представителя военных кругов, являлся весьма показательным.

В период «эры Секта» рейхсвер все более отдалялся от республики и воспитывался в духе, далеком от республиканского самосознания. Командование рейхсвера использовало кажущийся отказ от участия в политической жизни для разработки планов реализации долгосрочных насильственных целей, которым суждено было осуществиться лишь после того, как Гитлер в 1933 году окончательно ликвидировал ненавистную республику и пообещал создать авторитарное государство, в котором военные вновь должны были играть центральную роль.

Руководство рейхсвера воспринимало Веймарскую республику как преходящее явление. Они расценивали Версальский договор как временный этап на пути к реализации более широкого военного проекта. Сегодня известно достаточное количество источников, свидетельствующих о том, что после проигранной войны вновь принятые на военную службу офицеры кайзеровской Германии ни на минуту не отказывались от желания снова начать войну в ближайшем или отдаленном будущем. Ни поражение в 1918 г., ни революция, ни осуществленное по требованию держав-победительниц сокращение сухопутных сил до 100000 человек не смогли преодолеть великодержавную манию величия и веру во власть меча, которая станет характерной чертой уже нацистской Германии.

Передававшаяся из поколения в поколение вера в насилие сохранилась даже у тех, кто в определенной степени приспособился к новой внутриполитической ситуации и кого по этой причине называли «республиканцами по 


\section{Исторический журнал: научные исследования № 3 (27) • 2015}

DOI: $10.7256 / 2222-1972.2015 .3 .16520$

разуму». Это можно сказать, например, об относительно либерально настроенном генерале Вильгельме Грёнере, занимавшем до 1919 г. пост первого генерал-квартирмейстера в ОХЛ, а после этого служившем республике в качестве министра транспорта, министра внутренних дел и министра рейхсвера. Осенью 1919 г. он счел необходимым письменно предупредить Фридриха Әберта о недопустимости отказа от опоры на военных: «Мы ни в коем случае не должны позволить себе пойти на поводу у иллюзий пацифистских идеологов, будто с помощью подавления любых проявлений национального и воинственного духа нации можно обеспечить вечный мир и всеобщее благоденствие <... Лишь в непрекращающейся борьбе за жизнь укрепляются и закаляются духовные и нравственные силы, дающие народу крылья для полета. Народ, нарушающий этот закон природы, внутренне болен и обречен на гибель». Генерал требовал позаботиться о том, чтобы немецкий народ в последующие мирные годы мог вновь окрепнуть и снова вступить в борьбу против своих соседей «в той степени и с теми средствами, которые окажутся в его распоряжении» [12, 207].

Генерал Грёнер опасался того, что рейхспрезидент мог попасть под влияние пацифистских настроений, проявившихся в 1919 г. в качестве реакции на четыре года войны в форме массовых протестов и связанных с надеждой найти новые пути к миру при поддержке Лиги наций. Созданный в том же году «Союз участников войны, стремящихся к миру» (Friedensbund der Kriegsteilnehmer) подхватил популярный лозунг «Нет - новой войне!» В него вошли такие известные люди, как Карл фон Осецкий, Эмиль Юлиус Гумбель, Георг Фридрих Николаи, Курт Тухольский, Отто Леманн-Русбюлдт и редактор газеты СДПГ «Форвертс» Артур Циклер. В 1920 г. вместе с представителями других пацифистских организаций они образовали Комитет действий, который ежегодно 1 августа, в день начала мировой войны, организовывал массовые митинги, собиравшие сотни тысяч участников. Эти демонстрации по праву считались «основой для мобилизации масс против войны» [9]. В них участвовали СДПГ, Объединение немецких профсоюзов и другие организации демократического спектра, что демонстрировало наличие контуров республиканско-пацифистского союза, а именно этого опасались военные круги, поскольку такой союз ставил под вопрос будущее милитаристской государственной власти.
Так выглядела политическая альтернатива, перед которой Германия находилась после подписания Версальского мирного договора. Известный историк Фридрих Мейнеке писал сразу после окончания Второй мировой войны, что веймарская коалиция продемонстрировала твердую волю «терпеливо и медленно, посредством постоянных, даже весьма скромных компромиссов с державами-победительницами развязывать или как минимум ослаблять цепи Версальского мира. Тогда это был единственный возможный способ постепенно выпутаться из них. Любая другая возможность грозила рано или поздно привести к войне, а любая война, как это потом и произошло, вела к катастрофе для Германии» $[10,67]$.

Иными словами, можно было проводить политику мирного взаимопонимания, которая отнюдь не исключала будущий пересмотр Версальского договора, но означала отказ от милитаристской политики. С лета 1919 г. эта политика была отягощена тем, что даже демократические партии сочетали готовность к взаимопониманию с ревизионистскими требованиями. Имелся и другой вариант: попытаться с помощью политики тайного вооружения в обход условий Версаля создать военный потенциал для того, чтобы в подходящий момент использовать его для возобновления борьбы за восстановление позиций Германии в качестве великой мировой державы. Именно это имел в виду генерал Грёнер в процитированном выше обращении к Әберту.

В середине 20-х гг. именно генералы и высшие офицеры рейхсвера, никак не реагируя на поиски имперским правительством компромисса в области внешней политики, занимались восстановлением военного потенциала Германии. Под руководством генерала Секта с 1921 по 1925 г. в войсковом управлении рейхсвера разрабатывались стратегия и конкретные планы вооружения [7]. Представления Секта о значительном увеличении размеров вооруженных сил были обобщены в форме подробной и всеобъемлющей программы в «Большом плане» [4], разработанном штабом рейхсвера в обстановке строжайшей секретности в 1924-1925 гг.

За спиной имперского правительства и рейхстага главнокомандующий сухопутными войсками поручил войсковому управлению работать над созданием сухопутной армии в составе 2,8-3 миллионов человек, разбитой на 102 дивизии $[4,210]$, т. е. армии будущего, превосходя- 


\section{Проблемы войны и мира}

DOI: $10.7256 / 2222-1972.2015 .3 .16520$

щей в 28 раз размер вооруженных сил, которые Германия могла иметь по Версальскому договору. Вряд ли стало случайностью то, что германский вермахт к началу Второй мировой войны в 1939 г. имел именно такой численный состав. Разумеется, существовавшие в Веймарской республике ограниченные условия по восстановлению производства вооружений допускали реализацию этих планов лишь в самых начальных формах. Но то обстоятельство, что они были задуманы уже на таком раннем этапе, свидетельствует о постоянном стремлении руководства вооруженных сил к продолжению реализации германской политики мирового господства, лишь на время прерванной в результате поражения 1918 г.

Тем, кто пытался критиковать военных, было нелегко пробудить сознание германской общественности, чтобы та поняла истинные цели тайного вооружения, осуществление которого прикрывалось патриотическими лозунгами [5]. Все же один из них, сотрудник пацифистского периодического издания «Другая Германия» военный журналист Бертольд Якоб $[3,204]$, соратник известных публицистов Тухольского и Осецкого по «Союзу участников войны» и соавтор «Белой книги о черном рейхсвере» [14], владел соответствующей информацией. В открытом письме он писал министру рейхсвера Отто Гесслеру 11 апреля 1925 г.: «Вы должны знать, что господин фон Сект распорядился осуществить внутри рейхсвера все необходимые приготовления, которые должны позволить в нужный, с его точки зрения, момент превратить германский рейхсвер в восемь мобильных армий первого дня мобилизации 1914 года» $[2,3]$. Среди критиков тайного перевооружения в этот период также была горстка бывших профессиональных офицеров, которые, осознавая все последствия новой милитаристской политики, перешли в лагерь пацифистов и - как «офицеры-пацифисты» [15] - использовали свои профессиональные военные знания в интересах движения за мир.

Вернемся к исходному тезису о том, что важные причины крушения первой немецкой республики следует искать уже на раннем этапе ее существования. Писатель Теодор Пливер в 1932 г. охарактеризовал революционный переход Германии от кайзеровской империи к Веймарской республике весьма пессимистично: «Кайзер ушел, генералы остались» [18]. Хотя монархии и пришлось уступить свое место республике, одна- ко последней так и не удалось отстранить от власти кадровый резерв прусско-германского милитаризма, а именно - враждебно настроенную по отношению к ней профессиональную военщину. В конечном счете в результате столкновений 1919-1920 гг, схожих с гражданской войной, победила контрреволюция [7, 119].

Карл фон Осецкий видел это уже в 1921 г. В своей статье «Генезис германской реакции», опубликованной в швейцарской газете, он писал: «Сегодня роялисты сильны во всех государственных учреждениях, в рейхсвере и бюрократии, в церкви и школе. Республика находится в состоянии слабой обороны, за ее бедами с недоверием и злорадством наблюдают радикально настроенные рабочие, оказавшиеся во власти III Интернационала. Она предана своим аппаратом управления и брошена на произвол судьбы большей частью буржуазии, вновь молящейся старым богам. Без всякого зазрения совести подвергаются поруганию ее государственный строй и конституция. Рейхспрезидент и министры изза своей профессиональной деятельности становятся объектами необузданных оскорблений в печати, ведущих республиканцев называют государственными изменниками, пацифистски настроенные профессора подвергаются словесным и физическим нападкам со стороны юных студентов, украшенных свастикой, известных борцов за республику и идеи мира убивают “при попытке к бегству” как “спартаковцев”. При этом в каждом случае следствие не дает никаких результатов, а если и найдется суд, готовый привлечь преступника к ответственности, моментально обнаружится пассаж в каком-либо постановлении об амнистии, позволяющий обвиняемому избежать наказания» [6, 101].

Во время Первой мировой войны более 10 миллионов немцев носили военную форму. В период становления Веймарской республики этот огромный потенциал насилия удалось нейтрализовать далеко не полностью. Значительное число военнослужащих, не сумевших пристроиться в небольшом рейхсвере, сначала нашло прибежище в многочисленных фрайкорах, а потом и в нелегальных полувоенных объединениях [1]. Полувоенные формирования получили тогда меткое название «черный рейхсвер». Германская пацифистская «Лига за права человека» опубликовала в 1925 г. «Белую книгу о черном рейхсвере». В ней было показано, что он возник примерно в 1922-1923 гг. и охватывает формирования от «внешне безобидного военно-спор- 


\section{Исторический журнал: научные исследования № 3 (27) • 2015}

DOI: $10.7256 / 2222-1972.2015 .3 .16520$

тивного объединения, общества стрелков из малокалиберного оружия, тайного объединения, организованного строго по военному образцу $<\ldots>$ до соединений, которые уже практически невозможно отличить от легального рейхсвера» $[20,156]$.

«Черный рейхсвер» отнюдь не являлся фантомом, как пытался убедить германскую и международную общественность Отто Гесслер [20, 157]. Министр рейхсвера не мог допустить и мысли о том, что его задача заключалась в политическом контроле над армией, которая до 1918 г. находилась вне поля зрения парламентских структур. Еще одним средством военной подготовки мужчин за пределами предписанной армии численностью в 100000 человек стала система временной военной добровольческой службы [20, 158]. С ее помощью сухопутная армия Германии с 1923 г. в обход условий Версальского договора и за спиной у Международной военной контрольной комиссии заложила фундамент системы комплектования вооруженных сил, которую можно было бы использовать в случае объявления мобилизации или войны.

Количественный состав вооруженных сил Веймарской республики мало говорит о том духе милитаризма, который продолжал оказывать серьезное влияние на властные структуры. В существовавших тогда политических рамках он принимал форму милитаристских убеждений, которые, как это имело место еще в кайзеровской империи, среди большого числа гражданских лиц были распространены не меньше, чем среди военных [17]. Эти убеждения проявляли себя в непрерывности идеологии войны, передававшейся из поколения в поколение, в тайных планах вооружения, в создании обширной сети полувоенных организаций, в политическом и юридическом подавлении любого проявления пацифизма и в конечном итоге - в новом подъеме националистических и расистских движений.

11 октября 1931 г. эти движения объединились в союз, получивший название Гарцбургский фронт. Помимо Национал-социалистической германской рабочей партии (НСДАП) и Германской национальной народной партии (ГННП) в этот союз вошли правый Союз фронтовиков «Стальной шлем» и Объединение патриотических союзов. По прошествии еще полутора лет с помощью Гарцбургского фронта к власти в Германии пришел Адольф Гитлер.

\section{Библиография:}

1. Berghahn V. R. Der Stahlhelm. Bund der Frontsoldaten 1918-1935. Düsseldorf, 1966.

2. Das Andere Deutschland. Unabhängige Zeitung für entschieden republikanische Politik. Eine Auswahl (1925-1933) / Hrsg. und eingel. von H. Donat und L. Wieland: Königstein/Ts., 1980.

3. Die Friedensbewegung. Organisierter Pafizismus in Deutschland, Österreich und der Schweiz / Hrsg. von H. Donat und K. Holl. Düsseldorf,1983. S. $204 \mathrm{f}$.

4. Dirks C., Janssen K.-H. Der Krieg der Generäle. Hitler als Werkzeug der Wehrmacht. Berlin, 1999.

5. Donat H. Rüstungsexperte und Pazifist - Der ehemalige Reichswehroffizier Carl Mertens (1902-1932) // Wette W. (Hrsg.) Pazifistische Offiziere in Deutschland 1871-1933. Bremen, 1999. S. 247-271.

6. Donat H., Wild A. (Hrsg.) Carl von Ossietzky. Republikaner ohne Republik. Bremen, 1986.

7. Geyer M. Aufrüstung oder Sicherheit. Die Reichswehr in der Krise der Machtpolitik. Wiesbaden, 1980.

8. Höhn R. Sozialismus und Heer. Bd. III: Der Kampf des Heeres gegen die Sozialdemokratie. Bad Harzburg, 1969.

9. Lütgemeier-Davin R. Basismobilisierung gegen den Krieg: Die Nie-wieder-Krieg-Bewegung in der Weimarer Republik // Holl K., Wette W. (Hrsg.). Pazifismus in der Weimarer Republik. Beiträge zur Historischen Friedensforschung. Paderborn, 1981. S. 47-76.

10. Meinecke F. Die deutsche Katastrophe. Wiesbaden, 1946.

11. Mommsen H. Die verspielte Freiheit. Der Weg der Republik von Weimar in den Untergang 1918 bis 1933 . Berlin, 1989.

12. Schreiben des Ersten Generalquartiermeisters, Generalleutnant Wilhelm Groener, vom 17. September 1919 an Reichspräsident Friedrich Ebert // Bundesarchiv-Militärarchiv (BA-MA) Freiburg i. Br. Nachlass von Schleicher. № 42/12.

13. Ullrich V. Die Revolution von 1918-1919. München, 2009.

14. Weißbuch über die Schwarze Reichswehr. Deutschlands geheime Rüstungen? / Hrsg. von Gumbel E.J. u.a. Berlin, 1925.

15. Weiße Raben. Profile pazifistischer Offiziere 1871-1933 // Für eine lebendige Wissenschaft des Politischen/ hrsg. von T. Greven und O. Jarasch. Frankfurt am Main, 1999. S. 237-259.

16. Wette W. Gustav Noske. Eine politische Biographie. Düsseldorf, 2. Aufl. 1988.

17. Wette W. Militarismus in Deutschland. Geschichte einer kriegerischen Kultur. Frankfurt am Main, 2008.

18. Wette W. Noske-Ära: Die vertane Chance, mit dem preußisch-deutschen Militarismus zu brechen // Butenschön R., Spoo E. (Hrsg.). Wozu muss einer der Bluthund sein? Der Mehrheitssozialdemokrat Gustav Noske und der deutsche Militarismus des 20. Jahrhunderts. Heilbronn, 1997. S. 27-37.

19. Winkler H.A. Weimar 1918-1933. Die Geschichte der ersten deutschen Demokratie. München, 1993.

20. Wohlfeil R., Dollinger H. Die Deutsche Reichswehr. Bilder, Dokumente, Texte. Zur Geschichte des Hunderttausend-Mann-Heeres 1919-1933. Frankfurt am Main, 1972 


\section{Проблемы войны и мира}

DOI: $10.7256 / 2222-1972.2015 .3 .16520$

\section{References (transliterated):}

1. Berghahn V. R. Der Stahlhelm. Bund der Frontsoldaten 1918-1935. Düsseldorf, 1966.

2. Das Andere Deutschland. Unabhängige Zeitung für entschieden republikanische Politik. Eine Auswahl (1925-1933) / Hrsg. und eingel. von H. Donat und L. Wieland: Königstein/Ts., 1980.

3. Die Friedensbewegung. Organisierter Pafizismus in Deutschland, Österreich und der Schweiz / Hrsg. von H. Donat und K. Holl. Düsseldorf,1983. S. $204 \mathrm{f}$.

4. Dirks C., Janssen K.-H. Der Krieg der Generäle. Hitler als Werkzeug der Wehrmacht. Berlin, 1999.

5. Donat H. Rüstungsexperte und Pazifist - Der ehemalige Reichswehroffizier Carl Mertens (1902-1932) // Wette W. (Hrsg.) Pazifistische Offiziere in Deutschland 1871-1933. Bremen, 1999. S. 247-271.

6. Donat H., Wild A. (Hrsg.) Carl von Ossietzky. Republikaner ohne Republik. Bremen, 1986.

7. Geyer M. Aufrüstung oder Sicherheit. Die Reichswehr in der Krise der Machtpolitik. Wiesbaden, 1980.

8. Höhn R. Sozialismus und Heer. Bd. III: Der Kampf des Heeres gegen die Sozialdemokratie. Bad Harzburg, 1969.

9. Lütgemeier-Davin R. Basismobilisierung gegen den Krieg: Die Nie-wieder-Krieg-Bewegung in der Weimarer Republik // Holl K., Wette W. (Hrsg.). Pazifismus in der Weimarer Republik. Beiträge zur Historischen Friedensforschung. Paderborn, 1981. S. 47-76.

10. Meinecke F. Die deutsche Katastrophe. Wiesbaden, 1946.

11. Mommsen H. Die verspielte Freiheit. Der Weg der Republik von Weimar in den Untergang 1918 bis 1933. Berlin, 1989.

12. Schreiben des Ersten Generalquartiermeisters, Generalleutnant Wilhelm Groener, vom 17. September 1919 an Reichspräsident Friedrich Ebert // Bundesarchiv-Militärarchiv (BA-MA) Freiburg i. Br. Nachlass von Schleicher. № 42/12.

13. Ullrich V. Die Revolution von 1918-1919. München, 2009.

14. Weißbuch über die Schwarze Reichswehr. Deutschlands geheime Rüstungen? / Hrsg. von Gumbel E.J. u.a. Berlin, 1925.

15. Weiße Raben. Profile pazifistischer Offiziere 1871-1933 // Für eine lebendige Wissenschaft des Politischen/ hrsg. von T. Greven und O. Jarasch. Frankfurt am Main, 1999. S. 237-259.

16. Wette W. Gustav Noske. Eine politische Biographie. Düsseldorf, 2. Aufl. 1988.

17. Wette W. Militarismus in Deutschland. Geschichte einer kriegerischen Kultur. Frankfurt am Main, 2008.

18. Wette W. Noske-Ära: Die vertane Chance, mit dem preußisch-deutschen Militarismus zu brechen // Butenschön R., Spoo E. (Hrsg.). Wozu muss einer der Bluthund sein? Der Mehrheitssozialdemokrat Gustav Noske und der deutsche Militarismus des 20. Jahrhunderts. Heilbronn, 1997. S. 27-37.

19. Winkler H.A. Weimar 1918-1933. Die Geschichte der ersten deutschen Demokratie. München, 1993.

20. Wohlfeil R., Dollinger H. Die Deutsche Reichswehr. Bilder, Dokumente, Texte. Zur Geschichte des Hunderttausend-Mann-Heeres 1919-1933. Frankfurt am Main, 1972 